\title{
Research Paper Application of path analysis for contribution of reproductive traits in lactation milk yield of half breed cattle
}

See end of the paper for authors' affiliations

Correspondence to :

\section{S.D. SHINDE}

Department of Statistics, N.E.S. Science College, NANDED (M.S.) INDIA Email : badeshmukh@ gmail.com

Paper History :

Received : 24.08.2016;

Revised : 04.01.2017

Accepted : 14.01.2017
Abstract : The use of the path co-efficient analysis methodology in half breed cattle revealed that, the reproductive trait- lactation length (LL) had appreciable effect in total lactation milk yield (LMY). Correlation of LL with total LMY was highly significant ranges from 0.267 to 0.522. Direct effect of LL and indirect effects of SP and CI through LL were positive and higher in all lactations. The direct per cent contribution of LL in LMYwas 13.49 to 29.25 per cent. However, SP and CI showed negligible direct contribution in LMY upto $3^{\text {rd }}$ lactation and for $4^{\text {th }}$ to $6^{\text {th }}$ lactation ranged from 4.887 to 14.276 and 5.189 to 22.903 in LMY.AFC showed significant and negative correlation with LMY. Its direct effect also negative and indirect effects through other traits were negligible in LMY.That indicates early age of first calving increases the LMY in different lactations. Therefore, it is suggested that more emphasis may be given on these traits (AFC, SP, CL and LL) for future breeding programme.

KeY Words : Half breed cattle, Direct and indirect path co-efficients, Correlation co-efficient, Reproductive traits, LMY

How To Cite This PAPer : Jadhav, V.A. and Shinde, S.D. (2017). Application of path analysis for contribution of reproductive traits in lactation milk yield of half breed cattle. Internat. Res. J. Agric. Eco. \& Stat., 8 (1) : 15-20, DOI : 10.15740/HAS/IRJAES/8.1/15-20. 